\title{
Monitoring of recent mass movement activity in anthropogenic slopes of the Krušné Hory Mountains (Czech Republic)
}

\author{
J. Burda ${ }^{1,2}$, L. Žižka ${ }^{1}$, and J. Dohnal ${ }^{2}$ \\ ${ }^{1}$ Brown Coal Research Institute j.s.c., Most, Budovatelů 2830, Czech Republic \\ ${ }^{2}$ Faculty of Science, Charles University in Prague, Praha 2, Albertov 6, Czech Republic
}

Received: 16 September 2010 - Revised: 7 April 2011 - Accepted: 26 April 2011 - Published: 19 May 2011

\begin{abstract}
Recent mass movements currently comprise one of the main morphogenetic processes in the extensive anthropogenic relief of the foreground of the Krušné Hory Mountains in the Czech Republic. These mass movements result in several types of deep-seated slope failures, depending on the type of movement and the water saturation of the landslide material. This paper presents the results of a detailed geomorphic survey and orthophotograph analysis combined with geodetic monitoring data in an area affected by openpit coal mining. An interdisciplinary approach has enabled an in-depth review of both the dynamics and development of recent slope failures. The article describes deep-seated landslide complex in this part of the foothills of the Krušné Hory Mountains. At the study site, mass movements occur in thick colluvial mantle and weathered Tertiary claystones. The main factors influencing their development include rainfall culminations, groundwater flowing from the valley of Šramnický Brook and former slope failures. All of the slope failures that have occurred here have originated at former slope failure sites.
\end{abstract}

\section{Introduction}

The northwest part of the Czech Republic includes regions with a long tradition of brown coal mining. At the beginning of the second half of the 20th century, lignite mining was conducted in large open-pit mines. In many cases, this mining takes place in specific geological and geomorphic settings. The study area is located at a site where the side slopes of the Československá Armáda (ČSA) open-pit mine pass from the Mostecká Pánev Basin into the crystalline massif of the Krušné Hory Mountains (Fig. 1). Up until 2009, the

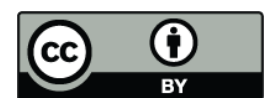

Correspondence to: J. Burda

(burda@vuhu.cz)
ČSA open-pit mine was the deepest mine in the Czech Republic, with a depth of about $200 \mathrm{~m}$. A high anthropogenic slope passes smoothly into the steep slopes of the Krušné Hory Mountains and involves a continuous 700 to $800 \mathrm{~m}$ high slope. Therefore, in connection with the intensive unloading of the basin and considering specific geological conditions (Marek, 1983; Horáček, 1994), the question of foothill slope instability arises, particularly around the Jezeři Castle, which is situated on a tectonically broken crystalline slope above the ČSA open-pit mine. To prevent relaxation of the crystalline massif around the Jezeří Castle, a protective pillar ${ }^{1}$ was left under a problematic part of the slope (Fig. 1b). A similar protective pillar was projected under Jezerka Mountain (about $2 \mathrm{~km}$ to the west), but due to landslides, the pillar was significantly reduced in the 1980s and 1990s. Consequently, the stability of the Jezeři protective pillar has been continuously monitored at 45 stabilized geodetic points by an automated total station since July 2005 (Stanislav and Blín, 2007). This kind of geodetic method is often used in monitoring open-pit mines (Brown et al., 2007); in northwest Bohemia it has been used since 1997 (Větrovský, 2002).

Many authors (Kalvoda et al., 1990, 1994; Rybář and Novotný, 2005; Rybář, 2006; Burda, 2010; Burda and Vilímek, 2010) point out that the stability of this anthropogenic slope is complicated by slope steepness, geological and geomorphic settings, as well as climatic factors. This study presents the results of field mapping, aerial orthophotograph interpretation, geophysical investigation and geodetic monitoring of the CSA slopes, revealing the dynamics of these mass movements. The objective of this study is the geomorphic interpretation of geodetic monitoring as well as confirmation of the influences of climatic factors on slope stability. Comparison with the results of geodetic monitor-

\footnotetext{
${ }^{1} \mathrm{~A}$ large block of solid material left unworked near the slope (in this case about 500 million $\mathrm{m}^{3}$ of original, undisturbed material above the coal seam)
}

Published by Copernicus Publications on behalf of the European Geosciences Union. 

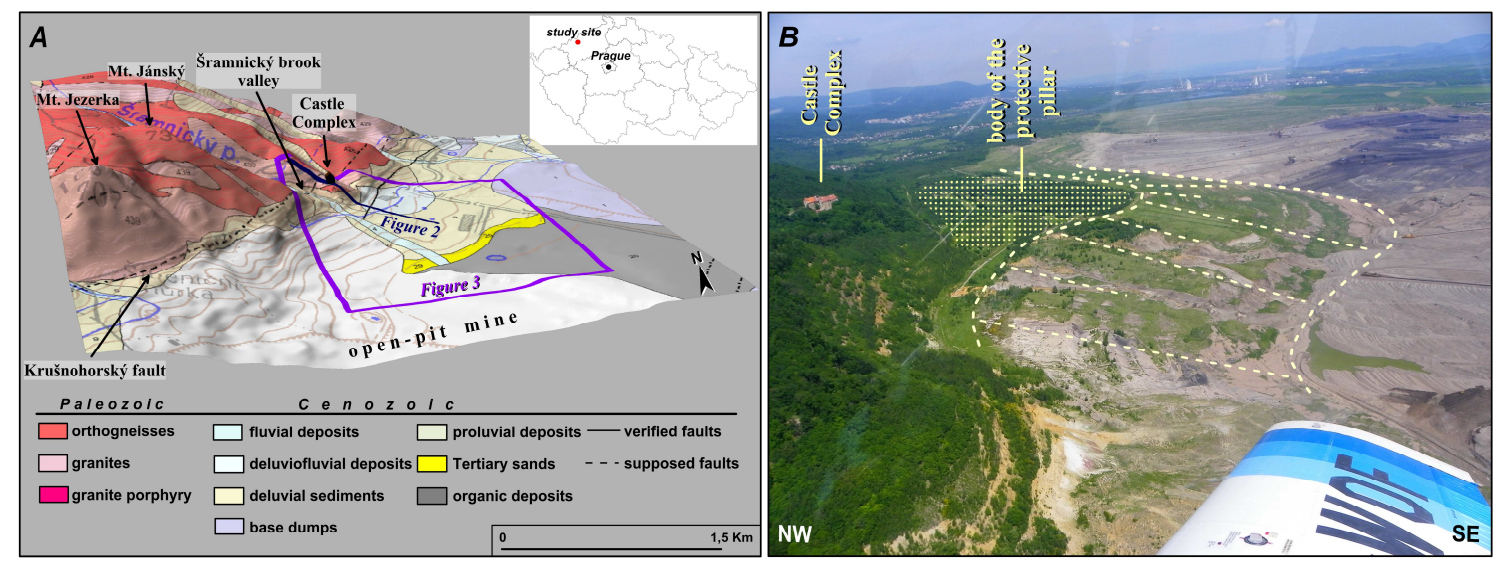

Fig. 1. General topographic and geological overview (A); aerial view of the study site; position of the protective pillar and surrounding overburden slope - dashed yellow lines (foto: J. Burda, 2010) (B).

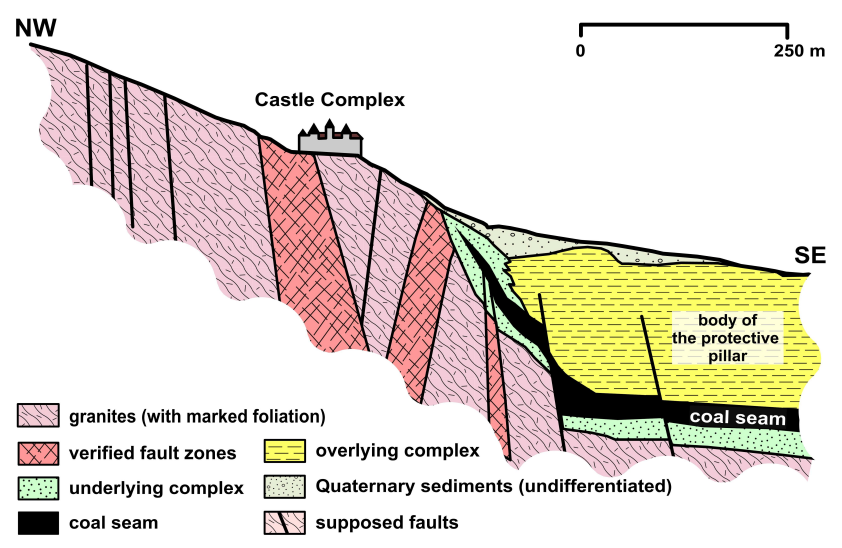

Fig. 2. Schematic geological cross-section through the edge of the Most Basin and Krušné Hory Mountains (modified after: Marek, 1983).

ing and data sets from the Jezeí meteo-station offers a unique opportunity to study the influence of climate factors on mass movement dynamics.

\section{General geological and geomorphic settings}

The study area (about $1.5 \mathrm{~km}^{2}$ ) is located at the foot of a southeast facing slope of the Krušné Hory Mountains made up of a portion of the Kateřinohorská Klenba (vault) in the physiographic province of the Krušné Hory Mountains and the Mostecká Pánev (basin).

The Kateřinohorská Vault has a flat anticline structure, whose axis approximately follows a west-east direction. The core of this vault consists of orthogneiss, which belongs to a packaging series of crystalline rocks (Fig. 1). According to Marek (1983), the foliation surface is fan-like with an inclination of $50^{\circ}$ to $70^{\circ}$. Crystalline rocks are characterized by the considerable density of fault zones in a NW-SE direction in the study area (Škvor, 1975). These fault zones occur even in the highest area of the massif and disrupt the bedrock, creating a system of blocks (Fig. 2). To prevent the bedrock from relaxing, during unloading after the excavation of the basin's sediments, a protective pillar was placed under the most problematic part of the slope.

The sediments of the Mostecká Basin consist of the underlying complex ${ }^{2}$ (mainly lower Miocene sandy-clays), coal seams and the overlying complex (upper Miocene claystones). The underlying complex is made up of sediments situated under the base of the coal seams. Stratigraphically, it is a heterogeneous unit with various Tertiary complex sediments (clays, sandstones and sands) as well as Cretaceous sediments (quartzite, sandstones, calcareous clays, marlites and limestones). Volcanic rocks (basalts, phonolites and tuffs) are also found in the underlying complex. The overlying complex is comprised of a group of clays and sandy-clays with variable occurrence of carbonates (Malkovský, 1985).

The overlying complex's border with the Quaternary sediments is problematic, especially in the immediate vicinity of the mountain slopes. The Quaternary sediments are made up primarily of coarse-grained gravel, sandy gravel and clays with crystalline fragments. The thickness of sediments varies from $0.1 \mathrm{~m}$ to $40 \mathrm{~m}$. Increasing thickness is characteristic of the areas where the alluvial fans of former tributaries are found. These alluvial fans contain mainly coarse grained gravel, sands, loam and fragments of crystalline. The fragments of crystalline can reach up to one to five meters in size. Near the Krušné Hory Mountains, there are zones with solitary boulders within gravel debris (Žižka and Halî̌, 2009).

These sediments represent a large saturated collector, wherein saturation depends on grain size composition, thickness and the content of clay components. The saturation of

\footnotetext{
${ }^{2}$ The overlying and underlying complexes are defined according to their position relative to the coal seam
} 


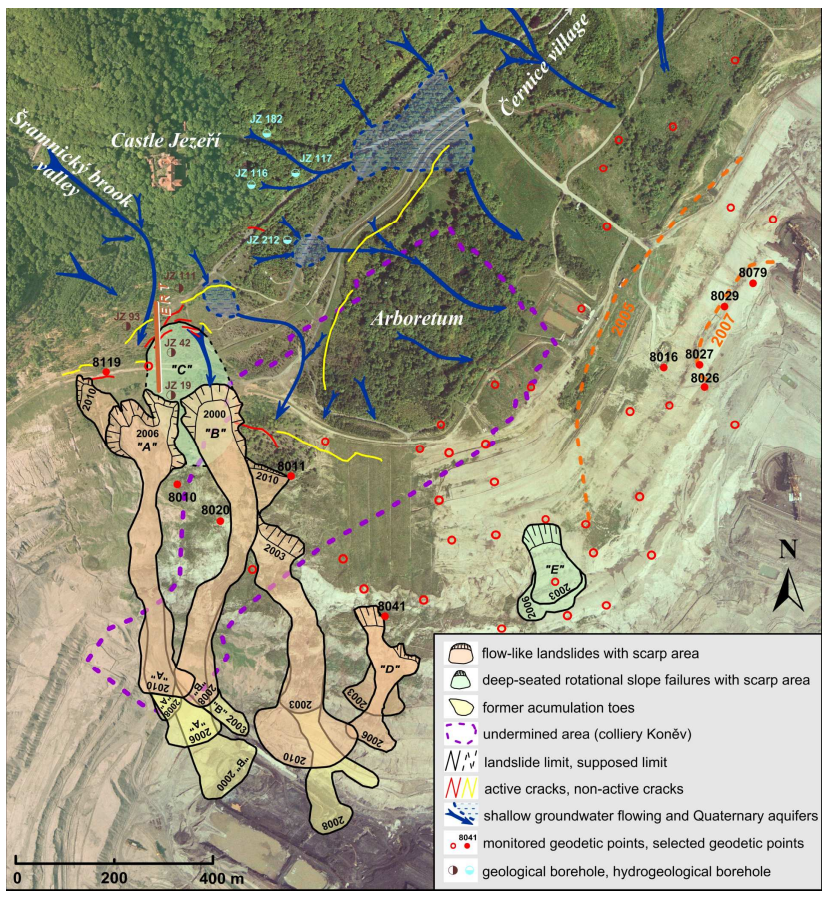

Fig. 3. Landslide inventory map of the Jezeí protective pillar area. The range of the landslides is based on geomorphic mapping and analysis of orthopohographs from 1987, 2000, 2003, 2006 and 2008. Dashed orange lines represent the approximate headscarps of the 2005 and 2007 slumps. The position of ERT profile is marked across the landslide "C". The underlying orthophoto map is from 2006, when the mining front was just under the protective pillar.

groundwater in the Quaternary sediments varies and depends on the factors listed. The gravels and sediments of alluvial fans have good permeability (up to $10^{-4} \mathrm{~m} \mathrm{~s}^{-1}$; Žižka and Halîr, 2009).

From a hydrological point-of-view, the study site is located within the Bílina River catchment. The original territory was drained naturally by Šramnický Brook, which had to be redirected into artificial channels to facilitate the development of coal mining. Since the 1980 s, the water from the entire Šramnický Brook catchment $\left(22 \mathrm{~km}^{2}\right)$ has been captured by a new channel, which diverts most of the water in a northeastern direction towards the village of ernice. To divert water from the surface horizons, several drainage ditches were also built into the talus cone near the former brook channel.

The Krušnohorský Fault, which has a dominant structuralgeological significance in this area, impacts the morphology of the study area (Kopecký et al., 1985; Vilímek, 1994). A southeast watershed slope rises above the Mostecká Basin with a very steep gradient - in some places more than $35^{\circ}$. Originally, a compact single watershed slope was significantly affected by erosion of the mountain brooks by periglacial and nival processes during the Pleistocene, as well as by large rockslides (Váně, 1960; Vilímek, 1995; Kalvoda et al., 1994).
Table 1. Values of absolute 3-D displacement of selected geodetic points.

\begin{tabular}{ll}
\hline Geodetic point & $\begin{array}{l}\text { Absolute 3-D } \\
\text { shift (2005-2009) }\end{array}$ \\
\hline 8010 & $291 \mathrm{~mm}$ \\
8011 & $284 \mathrm{~mm}$ \\
8016 & $445 \mathrm{~mm}$ \\
8020 & $859 \mathrm{~mm}$ \\
8026 & $776 \mathrm{~mm}$ \\
8027 & $884 \mathrm{~mm}$ \\
8029 & $10317 \mathrm{~mm}$ \\
8041 & $443 \mathrm{~mm}$ \\
8079 & $4528 \mathrm{~mm}$ \\
8119 & $322 \mathrm{~mm}$ \\
\hline
\end{tabular}

In the area where the ČSA open-pit mine is adjacent to the mountains, there is an anthropogenic slope created by overburden benches. The ČSA open-pit mine side-slope was projected in the 1980s and, at present, is further modelled by stream erosion and mass movements.

\section{Material and methods}

Detailed geomorphic field mapping was the first step in the research. We located the current limits and distribution of landslides, accumulation toes, scarps, erosion scarps and cracks. These basic slope-failures were mapped at all sites at a scale of 1:2000 and using GPS. Landslide activity and spatial characteristics were studied using sets of aerial orthophotographs from 1987, 2000, 2003, 2006 and 2008, and from aerial photos taken in June 2010 from on board Zlín-43, a civil aeroplane. Aerial orthophotographs were analyzed using Geographical Information System (GIS), which made it possible to reconstruct the studied mass movements as well as temporal activity and to roughly estimate horizontal displacement.

In this study we attempt to we interpret the results of geodetic monitoring. The Leica TCR 2003 automated total station monitors the positions of 45 stabilized geodetic points (reflecting prisms) at one-hour intervals. The reflecting prisms are attached to $3.5 \mathrm{~m}$ long stand pipes fixed with concrete at a depth of $2 \mathrm{~m}$. The automated total station is housed in a protective cab situated in a geologically stable area on the mined-out bottom of the ČSA open-pit mine (Stanislav and Blín, 2007).

An ATR system (Automatic Target Recognition) measures the return time of the laser beam reflected by the reflecting prisms every hour. The system calculates the location of the geodetic points and any resulting absolute (related to four geodetic reference points, located on the walls of service buildings and towers outside the open-pit mine) and relative 

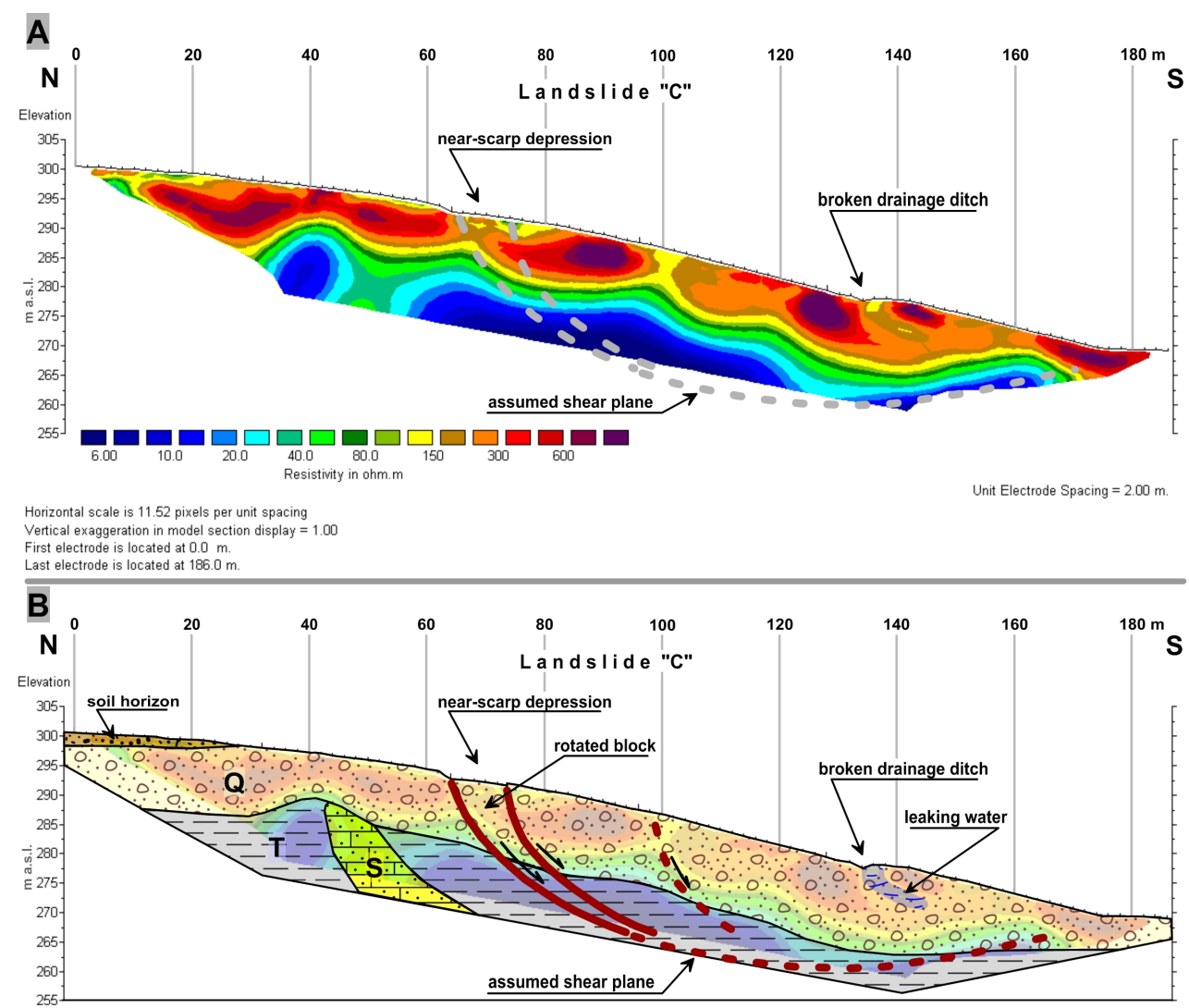

Fig. 4. ERT (electrical resistivity tomography) profile across the landslide "C" (A); Cross-sectional interpretation of ERT record (compared with rock cores from four nearest geological boreholes - see Fig. 2). Q - Quaternary colluvial deposits, T - weathered Tertiary clays (overlying complex), $\mathrm{S}$ - estimated position of Miocene sands (B).

(related to the previous location of the geodetic point) displacement is evaluated in 2-D and 3-D space. According to Hampacher et al. (2008), the error in calculating the zenith angle is statistically insignificant and therefore only 3-D displacement is analysed in this study. Considering the distances of 1400 to $1800 \mathrm{~m}$, measurement error is about 20 to $30 \mathrm{~mm}$ (Brown et al., 2007; Hampacher et al., 2008). Because the measurement error is relatively large, it was necessary to adjust the methodology to define limits for geodetic monitoring in this geomorphic research. We selected points, for which the 3-D shift reflects the mass movement's activity and exceeds the measurement error. Two criteria were employed in selecting such points: (1) continuous measurements throughout the 2005-2009 period; (2) values of absolute 3-D displacement, during this decade, exceed $250 \mathrm{~mm}$. This threshold was determined empirically so as to enable selection of a representative number of geodetic points, for which values of 3-D displacements significantly exceeded the measurement error. Ten points were chosen from all of the monitored geodetic points (the values of abs. 3-D shift are shown in Table 1). Either the absolute 3-D shift of the other geodetic points did not exceed $250 \mathrm{~mm}$ or their stabilization was destroyed (by landslide activity or heavy ma- chinery) and the criteria of continuous measurements were not met. The only exceptions are points 8079 and 8119 , which were established in June 2006 and in October 2007, respectively, and have been monitored up to the present day. Therefore they have been included in this study.

Data for each geodetic point (position and annual 3-D displacement) were transformed into geo-objects allowing for the spatial visualization of 3-D movements in GIS. Data were investigated with the Surfer 9 software in order to examine spatial relationships between all the geodetic points (Stoffel et al., 2005). Interpolations (Natural neighbour, grid size $30 \times 30 \mathrm{~m}$ ) were performed including data from each of the years $(2005,2006,2007,2008$ and 2009).

The structure and character of the deep-seated landslide was investigated using an electrical resistivity tomography (ERT) method. The research profile was performed across the most active part of the landslide body. It was $186 \mathrm{~m}$ in length with an azimuth of approximately $175^{\circ}$. The survey was carried out using a Resistar RS-100 instrument with a Wenner-Schlumberger configuration and an electrode spacing of $2 \mathrm{~m}$. The maximum depth of penetration was $20 \mathrm{~m}$. Field data was processed using a 2-D inverse method in Res2DInv program (Loke and Barker, 1995), resulting in a 
Table 2. Morphometric characteristics of active landslides "A" and "B" in the Western part of the protective pillar.

\begin{tabular}{lll}
\hline \multirow{2}{*}{ Characteristic } & \multicolumn{2}{c}{ Value } \\
\cline { 2 - 3 } & landslide "A" & landslide "B" \\
\hline Length & $800 \mathrm{~m}$ & $920 \mathrm{~m}$ \\
Width & $200 \mathrm{~m}$ & $125 \mathrm{~m}$ \\
Total surface & $58000 \mathrm{~m}^{2}$ & $130000 \mathrm{~m}^{2}$ \\
Total volume* & $400000-950000 \mathrm{~m}^{3}$ & $1.3-3 \mathrm{million} \mathrm{m}^{3}$ \\
Maximum depth & $13 \mathrm{~m}$ & $10 \mathrm{~m}$ \\
Maximum altitude (at crown) & $281 \mathrm{~m}$ & $272 \mathrm{~m}$ \\
Minimum altitude (at foot) & $154 \mathrm{~m}$ & $99 \mathrm{~m}$ \\
Difference of altitude & $127 \mathrm{~m}$ & $173 \mathrm{~m}$ \\
Average slope gradient & $13^{\circ}$ & $10.5^{\circ}$ \\
\hline
\end{tabular}

* According to formulas in Malamud et al. (2004).

resistivity cross section that included topography. The ERT record has been compared with rock cores from four surrounding geological boreholes (JZ 19, JZ 42, JZ 93 and JZ 111).

To confirm the existence of climatic influences, the 3D shifts of selected geodetic points were compared with monthly and daily precipitation. We used data sets from a meteo-station operated by the staff of Brown Coal Research Institute (BCRI). This station is referred to as the "Jezeří meteo-station" (294 $\mathrm{m}$ a.s.l.) in the following text. It is located above the castle arboretum and so the impact of torrential rain as a triggering factor for mass movement can be taken into account. There are four hydrogeological monitoring boreholes in the area of interest. The hydrogeological boreholes are situated in the Quaternary sediments (borehole JZ 212) and the crystalline complex (boreholes JZ 116, JZ 117, JZ 182). Data from the boreholes were used to compile a map of Quaternary aquifers and groundwater flow.

\section{Morphology and structure of landslides}

Based on the field mapping and orthophotographic analysis, several slope deformations were identified. As Fig. 3 shows, the surface of these landslides has changed as a result of landslide evolution but also due to dump construction.

Three active landslides "A", "B" and "C", which combine to form a landslide complex, were mapped in the western part of the study area. The landslide complex is situated in a non-reclaimed, anthropogenic slope and consists of two earthflows and a deep-seated rotational failure. The main morphometric characteristics of both earthflows are shown in Table 2. The westernmost landslide "A" consists of three connected rotational sub-landslides, measuring more than $10 \mathrm{~m}$ in thicknes. Only the west sub-landslide (from 2010) is active, the source areas of other two sub-landslides are completely empty, because the material has been transported out (during 2006) and thus the slip surface is clearly visible.
Their toes joined $50 \mathrm{~m}$ lower on the slope and transformed into an earthflow, which is continuous over all the overburden benches at the bottom of the ČSA open-pit mine. The former accumulation toe (from 2006) is now buried by dump material. The active part is $800 \mathrm{~m}$ long and, at most, $200 \mathrm{~m}$ wide with a total surface area of $58000 \mathrm{~m}^{2}$. According to Malamud et al. (2004), we estimated the total volume to be between 400000 and $950000 \mathrm{~m}^{3}$. The headscarp is 5 to $11 \mathrm{~m}$ high. Soil, colluvial sediments and weathered Tertiary complex sediments make up the visible outcrop in the headscarp. Several transverse cracks are located in the transport part of the landslide. The sharp - over $1.5 \mathrm{~m}$ high - linear side limits are morphologically dominant. The landslide body continues to be saturated with water and several springs have been mapped in the source area. The water streams flow over the landslides surface and accumulate in shallow ponds in depressions.

Landslide " $\mathrm{B}$ " is similar to landslide " $\mathrm{A}$ "; the material is transported in a large earthflow from a deep-seated source area. The surface of this landslide is $130000 \mathrm{~m}^{2}$, its maximum length is $920 \mathrm{~m}$, and its maximum width at the crown is $125 \mathrm{~m}$. The headscarp has a typical amphitheatre shape and only Quaternary sediments can be observed as outcrop. Several other headscarps (about $5 \mathrm{~m}$ high) are located lower in the middle part of the slope where mainly Tertiary claystones comprise the outcrop. The landslide body has a hummocky shape and the middle part of the slope is covered by young vegetation of initial succession (birch - Betula pendula). In its lower part, the landslide body is saturated with water accumulated in shallow ponds. Former accumulation toes have been covered by dump material as a result of dump advancement during recent years.

The two earthflows ("A" and "B") are divided by an indistinct ridge. The transported and accumulated material consists primarily of Quaternary debris but also includes weathered Tertiary clays. This fact, along with profiles over the headscarps, indicates that the slip surface passes through Tertiary claystones and that this occurs not only at the interference of Quaternary and Tertiary sediments.

The third active landslide, "C", is directly above landslides " $\mathrm{A}$ " and "B" and is bound by a significant headscarp with an apparent vertical displacement exceeding $1.5 \mathrm{~m}$. Active cracks were mapped 6 to $10 \mathrm{~m}$ below the headscarp and they limited rotated and sagged block. The minimal depth of shear plane estimated from the ERT profile is $14 \mathrm{~m}$ (Fig. 4). The resistivities along the profile span an interval of 5 to $800 \mathrm{ohm} \mathrm{m}$. The 3rd iteration's low RMS error of $3.5 \%$ supports the validity of the results. A relatively conductive (50 to $200 \mathrm{ohm} \mathrm{m}$ ) intermittent superficial layer in the northern part of the section reaches a depth of 0.5 to $2.5 \mathrm{~m}$ and represents the soil horizon. Below this layer there is lying a non-conductive (200-800 ohm m) material, corresponding to the presence of sandy and stony proluvial deposits from the Quaternary Period. The base of these sediments is situated at a depth ranging from $8 \mathrm{~m}$ (in the vicinity of stations 42 
and 162) to $13 \mathrm{~m}$ (in the vicinity of stations 28 and 140). The substratum is made up of markedly conductive material (less than ten ohm m) formed by weathered Tertiary clays with more sandy facies between stations 46 and 56. Two active cracks are manifested by sub-vertical conductive zones disrupting the high resistivity layer at stations 64 and 75 . Presently, a non-active crack is indicated in the same way at station 100 .

On the west side, the landslide is sharply limited by a transverse $60 \mathrm{~m}$ long crack; conversely its eastern edge is not clear because the headscarp fades away. Longitudinal and transverse cracks and scarps have been mapped all over the headscarp of this landslide. According to Rybár (1996), they originated in the 1990s.

In addition to this landslide complex, two smaller landslides (both a rotational - "E" and a flow-like landslide "D") were identified from the orthophotographs (Fig. 3). The movement of the flow-like landslide has also been recorded by geodetic point 8041 (total amplitude of displacement: $443 \mathrm{~mm}$ ), situated at the edge of the headscarp.

During 2007, a deep-seated slump developed in the eastern part of the protective pillar. Pichler (2007) estimated the minimal volume of this landslide to be $110000 \mathrm{~m}^{3}$, with a minimum depth of $11 \mathrm{~m}$ and width of $200 \mathrm{~m}$. The crown of this deep-seated rotational landslide was at $221 \mathrm{~m}$ a.s.l. and the toe at $210 \mathrm{~m}$ a.s.l. Many springs and streams were observed near the toe (E. Pichler, BCRI, personal communication, 2010). Because it is an operational slope face, slumps are routinely reclaimed immediately and it is not possible to map the range of such slumps accurately, not even with orthophotographs. As a result, it was impossible to map the exact limits of this slump (the assumed headscarp is shown in Fig. 3). The localization of the slump is also marked in Fig. 5 (in the western part of the monitored area where the displacement of two points reached as much as $9 \mathrm{~m}$ in 2007).

\section{Spatio-temporal analysis of landslide activity}

Every part of the monitored area exhibited different values of 3-D displacements over the 2005-2009 period. Based on the analysis presented in Fig. 5, we can define two zones that are characterized by the increased displacements values. Both zones coincide with the areas where slope deformations have been mapped. The first, the southwest zone corresponds to the site of the landslide complex. Based on the geodetic method described in this article, five geodetic points (nos. 8010, 8011, 8020, 8041 and 8119) were selected for an analysis of monthly 3-D displacement over the period from 2005 to 2009 (Fig. 6). Overall, the measured values fluctuated between 30 and $50 \mathrm{~mm}$. A slight increase in threshold values occurred between July 2006 and February 2007. Additional increases were evident during November 2007 and during the beginning of 2008 , when a jump in measured val- ues was evident at points 8020 and 8119 . A subsequent increase followed during the first quarter of 2009.

The spatial-temporal characteristics of this landslide area can be better estimated on the basis of orthophotograph set analysis. Landslide "A" was identified first on the orthophotograph from 2006, but the "B" landslide can be observed first on the 2000 orthophotograph and its spatial evolution is evident during the following years. In the most recent period, this landslide has only been active in the lower parts of the slope, in the transport and accumulation area.

The second zone of increased 3-D displacement values during the 2005-2009 period, is situated in the eastern part of the protective pillar. This part of the protective pillar was affected by deep-seated slumps in 2005 and 2007. As in the previous area, we chose several geodetic points to carry out an analysis of monthly 3-D displacement. Points no. $8016,8026,8027,8029$, and 8079 were selected. Altogether, the values fluctuated between 20 and $30 \mathrm{~mm}$ during the 2005-2009 period and such fluctuations are within the range of measurement error. Nonetheless, we can reliably identify months where landslide developments and significant shifts affected the monitored points. These months are at the end of 2005 and the beginning of 2006. Movements in September and November 2006 indicate a progressively evolving landslide. On 10 February 2007, primary movement activity of the landslide was observed in the middle part of the SE-facing slope. This trend is similar to the previous case, but the absolute displacements reached much larger values (point no. 8029:9352 $\mathrm{mm} \mathrm{month}^{-1}$, point no. $8079: 4154 \mathrm{~mm} \mathrm{month}^{-1}$ ). The activity was captured by eight geodetic points, but only points 8016, 8026, 8027, 8029 and 8079 were not destroyed during the landslide activity. The evolution of this slump has been reported since 2006, when measured displacements reached as much as $1 \mathrm{~m}$ (Fig. 5).

\section{Landslide triggers}

The immediate triggering factor for the landslide activity in the study area is the water saturation of landslide material, due to a combination of high cumulative rainfall and snow melt water that results in water table increase (Fig. 7). Increases in measured values of 3-D shift almost always coincide with sharp increases in the height of the water table. This is quite evident in the landslide on the SW-facing slope from 10 February 2007, where landslide activity was caused by long-term rainfall culmination (cumulative $118 \mathrm{~mm}$ vs. an average $22 \mathrm{~mm}$ ), which occurred during the 2007 snow-thaw period. At the end of January and into February, a sudden increase in average daily temperatures by more than $10^{\circ} \mathrm{C}$, occurred, leading to rapid snow melt and water table increase. The maximum daily temperature varied between 4.5 and $9{ }^{\circ} \mathrm{C}$ from 29 January through 9 February 2007. A similar trend of revival displacements, depending on increased water table 

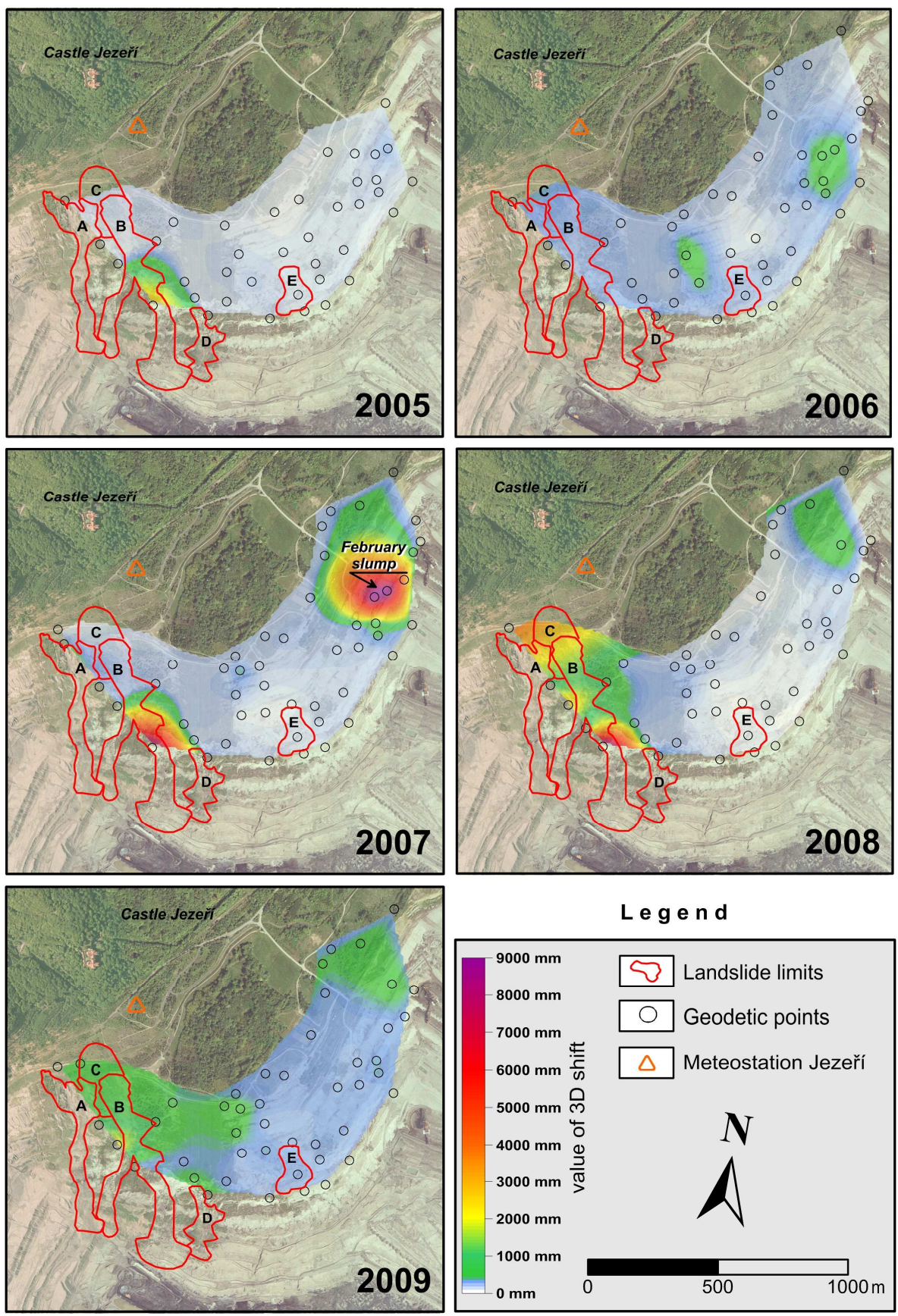

Fig. 5. Amplitudes of annual 3-D displacements. The patterns have been generalized based on interpolations.

levels, can be observed at the beginning of every year as well as during November 2007 (see Figs. 6 and 7).

In the same period of above-average rainfall during the beginning of 2008, an acceleration of movements was observed on the deep-seated landslide complex in the SW-facing slope. The most significant peak in movement (more than $150 \mathrm{~mm}$ per month) was observed with a one year delay on the SEfacing slope, but the landslide activity continues up to the present time.

\section{Discussion}

Information about groundwater flow, the configuration of the colluvial mantle as well as geodetic monitoring data and climatological data could further improve the prediction of spatial landslide hazards and the precision of geotechnical measures, thus minimizing any potential damage. 


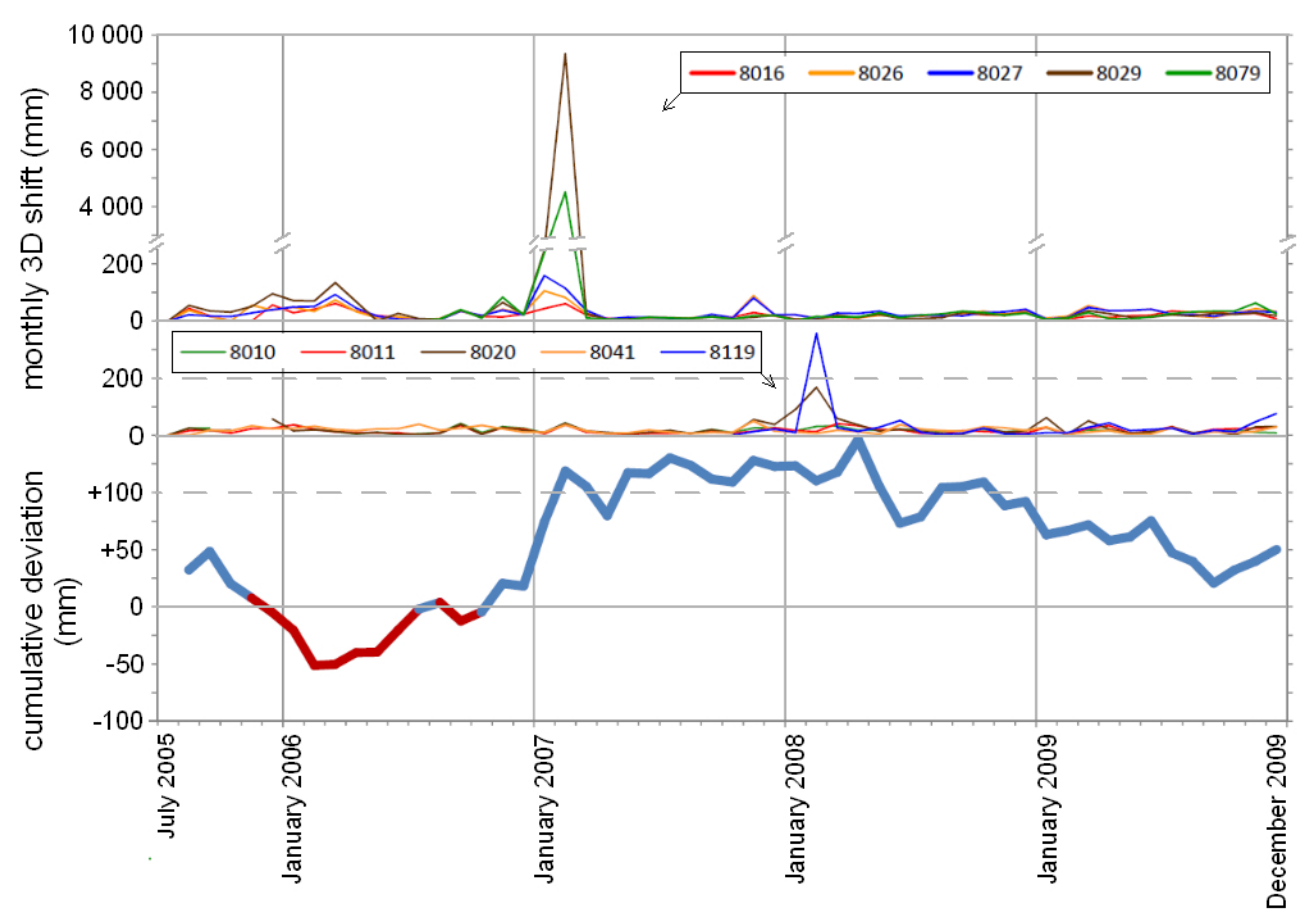

Fig. 6. Monthly 3-D displacements of selected geodetic points (top - SE facing slope, middle - SW facing slope). Cumulative deviations from average monthly rainfalls (bottom): above-average periods - blue line; subnormal periods - red line (Burda and Vilímek, 2010).

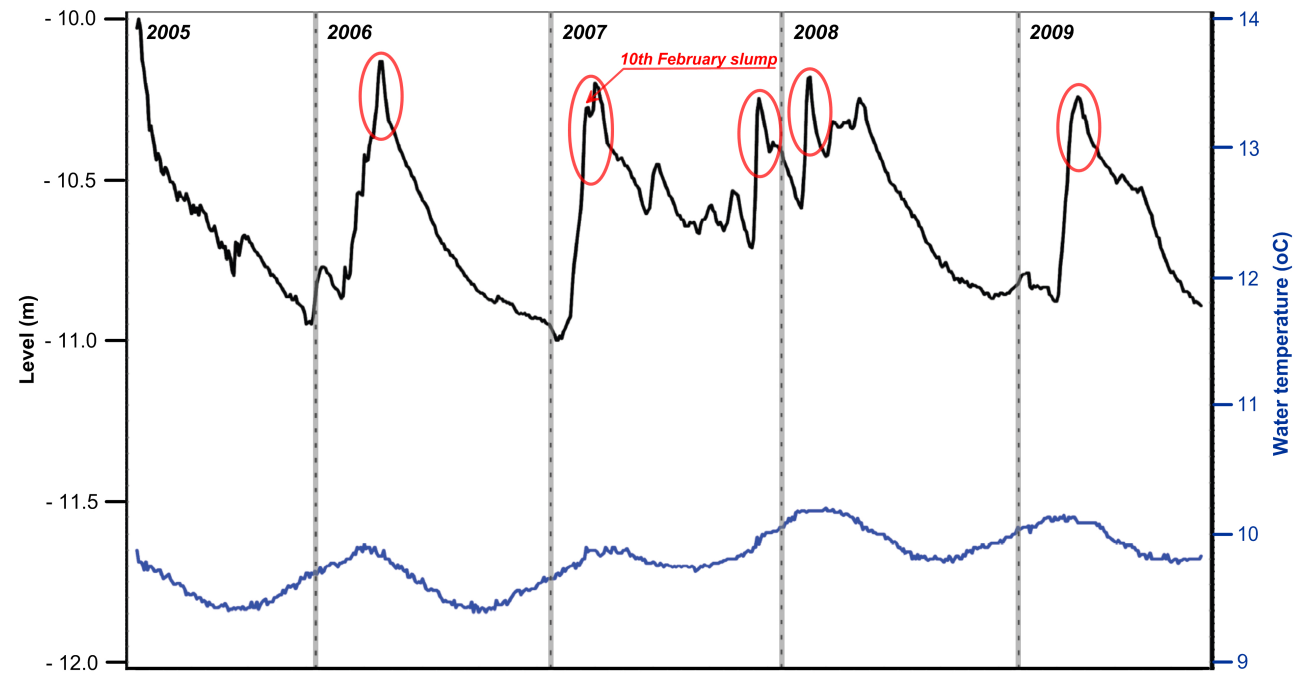

Fig. 7. Fluctuations of water table and water temperature in the JZ 212 borehole. Red marks indicate increasing groundwater level in the same period when values of 3-D shift increased (taken from: Chán et al., 2009).

The geodetic monitoring system described above was designed as an early warning system to prevent possible damage to equipment during mining activities. The main disadvantage of this method is its measurement error, which depending on the distance, can increase to 20 or $30 \mathrm{~mm}$. In particular, data from the early months of measurement should be considered with restraint, as the data is incomplete and the values of monthly shifts could be error prone as a result of the initial stages of measurement (see Stanislav and Blín, 2007). Therefore, the increased values of 3-D shift from the first months of 2005 cannot by reliably interpreted. Due to the appropriate selection of the geodetic points, we have been able to find points that accurately reflect the landslide activity. The treshold of absolute 3-D displacement of $250 \mathrm{~mm}$ is 
sufficiently exaggerated to enable us to state that it reliably reflects mass movement activity.

Another disadvantage of the geodetic monitoring is the considerable distance between selected points and thus, the low spatial coverage of area monitored with geodetic points. This fact does not allow the optimal placement of geodetic points, relative to the evolving landslide. Consequently, we estimated the velocity of the earthflows "A" and "B" on the basis of our analysis of geodetic points located mainly at the edges of the landslide bodies. Even so, these geodetic points are influenced by the landslide activity and so they showed continuously increased values of displacement. The actual velocity within the earthflow, however, is higher than the measured values. The fact that minimal values of displacement were measured on the southwest-facing slope from 2005 to 2007, despite the fact that according to orthophotographs and field mapping, the landslides evolved there can also be explained by the low density of geodetic points. Due to the nature of landslides, which exhibit the characteristics of a flow, it is not possible to stabilize geodetic points in the landslide bodies. Existing geodetic points which were installed in the landslide body were destroyed a short time after the main activity. Therefore, they could not be used for long-term analysis of landslide activity.

There are significant insufficiencies regarding this geodetic method when trying to analyse flow-like landslide dynamics. In general, this study shows that combinations of the methods used (geodetic monitoring data, geomorphic mapping, orthophotograph analysis, utilization of climate and hydrogeological data and geophysical investigation) can provide a powerful tool for the analysis of mass movement dynamics and their triggers in a significantly anthropogenicinfluenced area.

The findings demonstrate that the landslides are triggered by precipitation infiltration and the resulting water table increase. Rybář and Novotný (2005) and others (Rybář, 2006; Burda and Vilímek, 2010) have also discussed the influence of climatic factors in landslide occurrence. In general, they suggest that deep-seated landslides have occurred in the study area due to culmination of long-term precipitation with up to two years delay. The rotational landslide under Mt. Jezerka (Rybář and Novotný, 2005) is a typical and often-cited example of such slope failure (its depth was $50-60 \mathrm{~m}$ with a total volume of about 3 million $\mathrm{m}^{3}$ ). The main movement activity occurred in summer 1983, one and half years after the rainfall culmination. In contrast, the deep-seated landslides studied herein are evolving with no or minimal delay after long-term precipitation culminations.

This can be explained by a combination of two factors: (1) The study site is situated in the foreground of the mouth of the Šramnický Brook's valley; (2) Recent slope failures havecaused the slope to relax, which in turn has led to easier deep-soaking of rainfall water or snow-thaw water from the entire catchment area. Both parts of the protective pillar, where increased values were measured, have been affected by recent deep-seated landslides. The SE-facing slope collapsed completely in June 2005 (before monitoring began) as a result of a large deep-seated landslide, the volume of which was about 7 million $\mathrm{m}^{3}$ (Rybář and Novotný, 2005; see in Fig. 3).

The first cracks were mapped at the site of the landslide complex back in 1952 (Špurrek, 1974, BCRI archive). After this, part of the slope was undermined by the Konv underground mine (see in Fig. 3). The reactivation of these cracks has been evident since June 1990 (Rybár et al., 1996), with an average annual vertical drop of $28 \mathrm{~mm}$ in the body of landslide "C" (Pichler, 2007).

Although the area has been drained artificially, numerous springs in the landslide complex show that the triggering area is permanently saturated with groundwater. The lowest drainage ditch was even interrupted by landslide "A", during April 2010. Apparently, water gets to the source area from deeper horizons. This theory was also confirmed by an ERT investigation that revealed markedly conductive material in the Tertiary complex. It is probable that the extremely conductive part of these clays, situated at an average depth of 14 to $15 \mathrm{~m}$, is conditioned by weathered and water-saturated clays and represents an assumed water-bearing shear plane. The system of groundwater flow is affected by the configuration of the Quaternary structures and the crystalline roof. The source area corresponds to the mountain slopes and inflows of groundwater work their way through the disrupted crystalline roof with Quaternary sediments. The water table of the Quaternary aquifer is dependent entirely on precipitation and on water flowing from the adjacent slopes of the Krušné Hory Mountains and from the catchment of Šramnický Brook. The processed model of groundwater flow directions (see in Fig. 3) exactly matches the actual locations of observed water springs. The tributaries of these waters flows introduce complications and they are the main source of stability problems.

Despite detailed geomorphic mapping and the ERT investigation, the structure of landslide " $\mathrm{C}$ " is still not fully clear. The ERT investigation was limited by the maximum depth of penetration which was $20 \mathrm{~m}$. Ground water flowing along the interference of Quaternary and Tertiary sediments was reliably identified, but the maximum depth of the shear plane could be much greater (possibly up to $60 \mathrm{~m}$ as is the depth of the coal seam). In this case, it could be a slow moving, blockrotated, deep-seated failure similar to slope failures occurring in the Flysh Belt in the Czech Republic (Baron et al., 2004).

\section{Conclusions}

This study shows that large earth-flows and slumps evolved in specific anthropogenic relief near the foothills of the Krušné Hory Mountains. Specific geological, geomorphological and anthropogenic conditions have caused mass movements here to be similar to the Flysh Carpathians 
region, where the magnitude and dynamics of mass movements are greatest in the Czech Republic (Klimeš et al., 2009).

Two zones of high 3-D displacement values were found on the basis of geomorphic mapping, aerial orthophotographs and geodetic monitoring data analysis. The landslide complex, consisting of slow moving, deep-seated rotational failure and two earthflows, was mapped in the western part of the study area. Landslide mechanics in this part of the protective pillar are characterised by sliding slowly passing into flowing; however, due to measurement error, it is impossible to detect initial creep. The eastern part of the protective pillar was largely reclaimed during 2007 and, consequently, it was not possible to map slope failures from 2005 and 2007.

All of the selected geodetic points are usually in motion in the beginning of the year (January through March). In assessing the conditions in which the mass movements are developing, it is necessary to consider the combined influence of several factors. The landslide activity is triggered by the mutual effects of high cumulative precipitations and snow melt water. This results in high water tables and increased pore water pressure eventually leading to the mobilization of weathered claystones and overlaying Quaternary colluvial and alluvial sediments.

The fact that these deep-seated landslides occurred with no or minimal delay following precipitation culmination (Fig. 6) indicates that water is quickly soaking to deeper horizons. This is apparently the consequence of the thickness of the colluvial mantle, saturated by ground water from the Šramnický Brook catchment and former slope failures which occurred in 1952 and 2005 and led to the relaxation of the slope.

Generally speaking, detailed field mapping in this area of significant anthropogenic influence is difficult and so most of the landslides could only be mapped from orthophotographs. Groundwork, reclamations and dump advancing led to significant changes in the landslide surface and to the burial of former accumulation toes. Therefore, the estimated landslide characteristics presented above are only indicative and the total volume and surface area could actually be higher.

In subsequent years, the results of this research will be supplemented with three additional ERT profiles and the dynamic of the landslide complex will be monitored by a terrestrial LIDAR system from the beginning of 2011 onwards. The results will be used for planning reclamation and groundwork following the end of coal mining in the area.

Acknowledgements. The research was supported by these projects:

- Grant Project of Charles University in Prague (GAUK) No. 155610: "Analysis of recent mass movement distribution and their dynamic in the Jezeři area, Krušné Hory Mountains."

- MŠMT 1M06007: "Research Centre for Integrated System of Side Products Use from Energy Sources Exploitation, Preparation and Processing"
- Grant SVV-2011-261 201: "Research on the physicalgeographical changes in the natural environment of the Earth"

Edited by: A. Günther

Reviewed by: I. Baron and another anonymous referee

\section{References}

Baron, I., Cilek, V., Krejci, O., Melichar, R., and Hubatka, F.: Structure and dynamics of deep-seated slope failures in the Magura Flysch Nappe, outer Western Carpathians (Czech Republic), Nat. Hazards Earth Syst. Sci., 4, 549-562, doi:10.5194/nhess-4-5492004, 2004.

Brown, N., Kaloustian, S., and Roeckle, M.: Monitoring of Open Pit Mines using Combined GNSS Satellite Receivers and Robotic Total Stations, http://www.leica-geosystems. com/downloads123/zz/monitoring/geomos/tech_paper/Brown_ Monitoring_with_combined_GNSS_and_robotic_total_stations. pdf, 2007.

Burda, J.: Dendrogeomorphological analysis of mass movement in the Jezeři Chateau area, Geografie, 115 (4), 440-460, 2010.

Burda, J. and Vilímek, V.: The influence of climate effects and fluctuations in groundwater level on the stability of anthropogenic foothill slopes in the Krušné Hory Mountains, Czechia, Geografie, 115 (4), 377-392, 2010.

Chán, B., Mrlina, J., Seidl, M., Polák, V., and Skalský, P.: Monitoring of inclinations and water table in the area Jezeri, Expert opinion, Institute of Geophysic, Prague, 26 pp., 2009.

Hampacher, M., Jiř́ḱkovský, T., and Koska, B.: Automated monitoring of side slopes of the ĊSA open-pit mine, Expert opinion, Czech. Tech. Univ., Prague, 19, 2008.

Horáček, M.: Comparison of knowledge on the exploration of mining works between Jezerka and Horní Jietín in the Krušné hory Mts., Sbor. Geol. Vìd, 20, 45-51, 1994.

Kalvoda J., Stemberk J., Vilímek V., and Zeman A.: Analysis of levelling measurements of the Earth's surface movements on the geodynamic polygon Mikulovice - Jezeři in the Krušné hory Mts, Proc. 6th Int. IAEG Cong., 3, 1631-1637, 1990.

Kalvoda, J., Vilímek, V., and Zeman, A.: Earth's surface movements in the hazardous area of Jezeí castle - Krušné hory mountains, Geojournal, 32 (3), 247-252, 1994.

Klimeš, J., Baron, I., Pánek, T., Kosacík, T., Burda, J., Kresta, F., and Hradecký, J.: Investigation of recent catastrophic landslides in the flysch belt of Outer Western Carpathians (Czech Republic): progress towards better hazard assessment, Nat. Hazards Earth Syst. Sci., 9, 119-128, doi:10.5194/nhess-9-119-2009, 2009.

Kopecký, L., Kvìt, R., and Marek, J.: The question of the existence of Krušné hory Mts. fault zone, Ústř. Úst. Geol., 6, 164-168, 1985.

Loke, M. H. and Barker, R. D.: Least-squares deconvolution of apparent resistivity pseudosections, Geophys., 60, 1682-1690, 1995.

Malamud, B. D., Turcotte, D. L., Guzzeti, F., and Reichenbach, P.: Lanslides inventories and their statistical properties, Earth Proc. Surf. Land., 29, 687-711, 2004.

Malkovský, M.: Geology of the North Bohemian brown coal basin and its surroundings, Prague, 424 pp., 1985. 
Marek, J.: Problems of the Jezeří castle in the Krušné hory Mts., after completion of engineering-geological survey, Památ. a Pír., 8 (4), 228-237, 1983.

Pichler, E.: Continuous evaluation of monitoring of the side slopes of the ČSA open-pit mine and the technical supervision of the ČSA open-pit mine, Expert opinion, Brown Coal Research Institute j.s.c., 44 pp., 2007.

Rybár, J.: Evaluation of control monitoring of side slopes of the CŠA open-pit mine in the period 1983-1996, Final Report 205/94/1769, Prague, 11, 1996.

Rybár, J. and Novotný, J.: Impact of climatic factors on stability of natural and anthropogenous slopes, Zpravodaj Hnědé uhlí, 3, 13-28, 2005.

Rybář, J.: Climatic effects in the development of different types of slope movements, Zpr. Geol. Výz., 90-92, 2006.

Škvor, V.: Geology of the Czech Krušné hory Mts. and Smrèiny Mts., Prague, 1975.

Špůrek, M.: Landslide phenomena at Dř́nov, Vst. Ústř. Úst. Geol., 49, 231-234, 1974.
Stanislav, P. and Blín, J.: The technical requirements for operation of the Leica TCR 2003A automated total station in working conditions of the Mostecká uhelná company, Acta Monta. Slov., 12, 554-558, 2007.

Stoffel, M.: Analyzing rockfall activity (1600-2002) in a protection forest a case study using dendrogeomorphology, Geomorphology, 68, 224-241, 2005.

Váně, M.: Debris and landslides at the foot of the krušné hory Mts., Čas. Min. Geol., 5 (2), 174-177, 1960.

Větrovský, M.: Experience with monitoring deformations of slopes by the LEICA TCA 1800 automatic total station, Zpravodaj Hnědé uhlí, 1, 5-10, 2002.

Vilímek, V.: Summary of geomorphological researches in middle part of the Krušné hory Mts., Geografie, 99 (1), 29-38, 1994.

Vilímek, V.: Quaternary development of Kateřinohorská Vault relief in the Krušné hory Mountains, Acta Univ. Carol., 30, 115-137, 1995.

Žižka, L. and Halîŕ, J.: Geological model of the Quaternary sediments, Model CARE, 583-585, 2009. 